\title{
Influence of location in a salt marsh on survivorship of ribbed mussels
}

\author{
Junda Lin \\ Institute of Marine Sciences, University of North Carolina at Chapel Hill, Morehead City, North Carolina 28557, USA
}

\begin{abstract}
To assess how predation on ribbed mussels Geukensia demissa varied with tidal elevation and distance into the salt marsh, identical mussel clumps were introduced into locations differing in elevation and distance from open water in salt marshes at 2 geographically separate areas. Mussel mortality was greater at lower tidal elevations. At similar tidal elevations, mussels on the marsh interior showed less mortality than those on the marsh edge. Mortality was most likely due to predation by blue crabs Callinectes sapidus. Blue crabs and other aquatic predators forage in the salt marsh only during periods of tidal inundation and thus their feeding time decreases from low to high levels. At similar tidal elevations, their access to the marsh interior may be impeded by dense marsh grasses.
\end{abstract}

\section{INTRODUCTION}

The intensity of predation at different tidal elevations in the rocky intertidal zone has received much attention in the last $30 \mathrm{yr}$ (e.g. Connell 1961a, b, 1970, 1975. Dayton 1971, Menge 1978, 1983, Menge \& Lubchenco 1981, Underwood \& Denley 1984, Irons et al. 1986). These studies have demonstrated that the impacts of predators on their prey generally decrease from low to high elevations (but see Menge \& Lubchenco 1981, Frank 1982, Marsh 1986). However, the influence of elevation on the intensity of predation has been largely ignored in studies on soft sediments (Kneib 1984). Many of the important predators in intertidal soft-sediment communities are aquatic animals that forage there only during the periods of tidal inundation. Therefore, the intensity of predation by those predators should also decrease with increasing tidal height. The opposite pattern may be expected, however, for predation by wading birds and terrestrial mammals which forage in the intertidal zone only at low tide.

In a salt marsh, not only the elevation, but also the horizontal distance from the marsh edge may affect predation intensity by aquatic animals and wading birds because dense grasses impede travel to the marsh interior. On the other hand, the intensity of predation by terrestrial mammals (e.g. raccoons) might increase towards the higher edge of a marsh.

The present study investigates the effects of tidal elevation and the distance from open water on mortality of the Atlantic ribbed mussel Geukensia demissa (D.), a major component of the macrofauna in the marshes along the Atlantic and Gulf coast of North America (Bertness 1984, West \& Williams 1986). Most ribbed mussels live in aggregations (Kuenzler 1961, Stiven \& Kuenzler 1979, Bertness \& Grosholz 1985, Lin 1989), which significantly enhances their survivorship (Bertness \& Grosholz 1985). In this study, I introduced identical mussel clumps to different locations in salt marshes to measure mortality as a function of tidal elevation and distance from open water. Two geographically separate areas with very different tidal amplitudes were chosen to test the generality of the pattern.

\section{METHODS AND MATERIALS}

Study areas. The first geographic area was near Morehead City, North Carolina, USA, where the mean tidal range is about $1 \mathrm{~m}$; the second was on Sapelo Island, Georgia, USA, where the mean tidal range is about $2.5 \mathrm{~m}$ (U.S. Dept Commerce et al. 1988). Two marshes (Tar Landing and Causeway), each bordering a tidal creek, were chosen from the Morehead City area. Stiven \& Kuenzler (1979) provided detailed descriptions of these 2 marshes. The marsh on Sapelo Island was located near the Marine Institute of the University of Georgia. This marsh borders a tidal channel of several meters width. Extensive stands of Spartina alterniflora dominated all 3 marshes. 
At both Tar Landing and Causeway marshes, I chose 3 locations. Two locations ('Edge, Low' and 'Edge, High') were both 20 to $30 \mathrm{~cm}$ in from the lower margin of the marsh, although location Edge, Low was about $30 \mathrm{~cm}$ and Edge, High about $55 \mathrm{~cm}$ above mean low water level (Lin 1989). Another location ('Interior, High') was 15 to $18 \mathrm{~m}$ inward from the nearest marsh edge but only about $5 \mathrm{~cm}$ higher in elevation than Edge, High. At the Sapelo Island marsh, since the tidal amplitude was much greater and the mussels distributed further into the interior of the marsh (Table 1), 5

Table 1. Geukensia demissa densities (number $\mathrm{mn}^{-2} \pm \mathrm{SE}$ ) at different locations within the marshes. At 2 Morehead City marshes, both locations were at similar tidal elevations with Locations 'Edge, High' and 'Interior, High' about 02. to 0.3 and 15 to $18 \mathrm{~m}$ inward from the marsh edge, respectively. Location 'Edge, Low' was not sampled. At the Sapelo Island marsh, no mussel occurred at Locations 1 to 3 (all at marsh edge with different tidal elevations). Locations 4,5 , and 6 were at same tidal elevation with 15 to 20,30 to 35 , and 45 to $50 \mathrm{~m}$ from the marsh edge, respectively

\begin{tabular}{|c|c|c|}
\hline \multirow[t]{2}{*}{ Location } & \multicolumn{2}{|c|}{ Morehead City } \\
\hline & Tar Landing & Causeway \\
\hline 'Edge, High' & $13.2 \pm 4.1$ & $37.8 \pm 9.7$ \\
\hline \multirow[t]{2}{*}{ 'Interior, High' } & $1.2 \pm 0.6$ & $2.8 \pm 1.2$ \\
\hline & \multicolumn{2}{|c|}{ Sapelo Island } \\
\hline 4 & \multicolumn{2}{|c|}{$12.4 \pm 3.2$} \\
\hline 5 & \multicolumn{2}{|c|}{$11.2 \pm 2.4$} \\
\hline 6 & \multicolumn{2}{|c|}{$7.8 \pm 2.8$} \\
\hline
\end{tabular}

locations were chosen (Locations 1, 2, 3, 4, and 5). Locations 1, 2, and 3 were all positioned 20 to $30 \mathrm{~cm}$ inward from the marsh edge. Location 2 was $35 \mathrm{~cm}$ higher in vertical elevation than 1, while 3 was $80 \mathrm{~cm}$ higher than 2. Locations 3,4 , and 5 were all at the same tidal elevation (marsh flat) at $0.25,15$ to 20 and 30 to $35 \mathrm{~m}$, respectively, from the nearest marsh edge.

Estimation of mussel density. Natural densities of mussels at different locations were estimated by haphazardly placing twenty $0.25 \mathrm{~m}^{2}$ quadrats at Locations 1 through 5 in the Sapelo Island marsh on May 26 and 27,1988 . One additional location (6), which was at the same elevation as Locations 3 to 5 and 45 to $50 \mathrm{~m}$ from the marsh edge, was also sampled. Locations Edge, High and Interior, High of Tar Landing and Causeway marshes were similarly sampled on June 15 and 16, 1988. Location Edge, Low was not sampled because only small and widely scattered Spartina patches extended down to this low tidal elevation, although mussels did naturally occur there. In each quadrat, all living mussels were located, removed and measured (shell height, anterior to posterior margin \pm $0.1 \mathrm{~mm})$.

Construction of mussel clumps. I used nylon threads (Dritz Co., S. Carolina) as artificial byssal threads to achieve desired attachment strengths in constructing mussel clumps. The addition of each thread required $0.5 \mathrm{~kg}$ more force to break a parallel connection. To create a mussel clump, the desired number of threads were tied together at both ends and one end of the thread bundle was tied to a small piece $(8 \times 5 \mathrm{~mm})$ of canvas which was glued onto the umbo region of the mussel with 'super glue' (Super Glue Corp., New York, USA). The other end was tied to a 12-gauge electric cord, which in turn was tied to a brick $(19 \times 9 \times 5.5 \mathrm{~cm})$ weighing $1.9 \mathrm{~kg}$.

Mussels with shell heights between 60 and $70 \mathrm{~mm}$ were collected from the Tar Landing and Causeway marshes, and from the Sapelo Island marsh. They were brought back to the Institute of Marine Sciences, University of North Carolina at Chapel Hill, and the Marine Institute of the University of Georgia, respectively. One nylon thread bundle composed of 8 threads equivalent to $4.0 \mathrm{~kg}$ in strength, which was about the average force $(4.09 \mathrm{~kg}, \mathrm{SE}=0.21, n=12)$ required to pull off a mussel of this size class in the Morehead City marshes as measured with a spring scale, was attached to each mussel as described above. Three mussels were tied to each electric cord and 4 electric cords were in turn tied in parallel to one brick. Thus there were 12 mussels on each brick which represented one mussel clump.

Field experiment. Between August 15 and 26, 1987 , 4 mussel clumps were put out at each of 3 locations (Edge, Low; Edge, High; Interior, High) in each of the 2 Morehead City marshes (Tar Landing and Causeway). The clumps were buried with the posterior portion of each mussel (about $25 \%$ of the shell height) exposed above the sediment. The 6 mussels tied to the 2 middle electric cords were classified as living in the center of the clump (all sides of each mussel surrounded and in contact with neighboring mussels; Okamura 1986) and the other 6 , tied to the 2 outer cords, were classified as inhabiting the edge of the clump (at least one side that had no contact with a neighboring mussel; Okamura 1986). Each clump was checked after $24 \mathrm{~h}$ and the number of mussels missing at each position (center and edge) was recorded. On June 28, 1988, another 4 clumps similarly constructed were put out at each location of both marshes and checked $24 \mathrm{~h}$ later. Missing mussels were replaced with ones of the same size class. The mussels used to replace the missing ones had already been tied with nylon threads in the laboratory and were tied to the electric cords in the field. The clump was then moved to another spot with a similar tidal elevation and distance from the marsh edge (pre- 
viously measured). The mussels were checked again 24 h later (on June 30, 1988). Replicates at each location were spaced at $20 \mathrm{~m}$ intervals.

At the Sapelo Island marsh, mussel clumps were constructed similarly. Five clumps were established at each of the 5 locations (1 to 5) on May 24 and 27, 1988, respectively. The clumps were checked and mortality recorded $24 \mathrm{~h}$ later, as described above. At each location, the distance between neighboring experimental mussel clumps was about $15 \mathrm{~m}$. All the locations studied at the Morehead City marshes were inundated during high tide periods, even during neap tides. At the Sapelo Island marsh, however, tidal water did not cover the marsh flat (Locations 3 to 5) between May 24 and 25, but covered all locations between May 27 and 28 . 1988 during high tide periods. This offered an opportunity to estimate the potential predatory intensity of terrestrial mammals on exposed mussel clumps. Between May 25 and 27, 1988, the mussel clumps of Locations 3 to 5 were left out in the field and checked every $24 \mathrm{~h}$.

\section{RESULTS}

\section{Mussel density}

At Tar Landing and Causeway marshes, average densities of mussels at Location Edge, High were significantly higher than those at Interior, High ( $t$-test, $p<0.05$; Table 1). At the Sapelo Island marsh, no mussels occurred at the marsh edge at any tidal elevations (Locations 1 to 3), whereas Locations 4 to 6 showed similar mussel densities as tested by Tukey multiple comparison test ( $p>0.05$; Table 1$)$.

\section{Field experiment}

Around almost all the experimental mussel clumps I found pieces of broken mussel shells with characteristic crab breakage (Hughes \& Seed 1981; pers. obs.). The predators generally pulled off the mussels before consumption as suggested by the broken nylon threads.

Multivariate analysis of variance (MANOVA) was used in analysing the mortality pattern of mussels because the 2 dependent variables, number of mussels missing from 2 positions (center and edge) within each clump were not independent.

For Morehead City marshes, a Model I 3-factor [Location (Edge, Low; Edge, High; Interior, High), marsh (Tar Landing; Causeway), and year (1987; 1988)] MANOVA revealed that except for location (Wilks' Lambda, $F_{4 / 118}=8.11, p<0.0001$ ), none of the factors nor their 2- and 3-way interactions had significant effects $(p>0.05)$ on the number of mussels missing (Cochran's test of homogeneity showed no significant difference in variance among the treatments at 0.05 level).

Because location was the only significant factor affecting mussel mortality and the number of mussels missing from 2 positions was highly correlated (the first characteristic root is $>88 \%$ for each factor and interaction term), data were pooled over marshes and years to compare mortality among locations for mussels living at either position within the clumps (Fig. 1). A Tukey

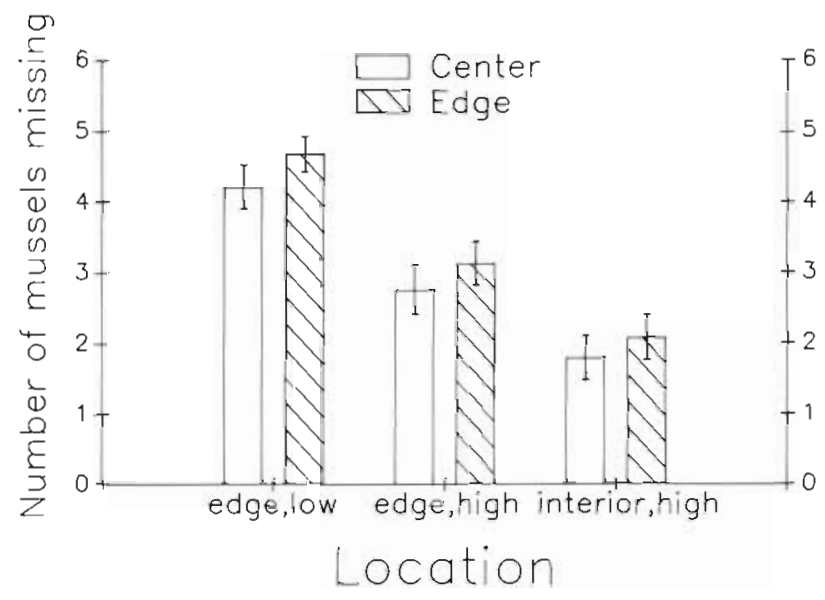

Fig. 1. Geukensia demissa. Mean number of mussels missing ( \pm SE) from 2 positions within clumps at 3 locations in 2 Morehead City marshes. Sample size for each bar $=24$

multiple comparison test showed that there were significant differences $(\alpha<0.05)$ in mussel disappearance rates among locations in the following order: Edge, Low $>$ Edge, High $>$ Interior, High for mussels living either in the center or on the edge of the clumps.

To compare missing rates of mussels between 2 positions (center and edge) within the ciumps, i calculated for each clump the proportion of mussels missing at each position and the difference between the 2 proportions. The calculation of differences is necessary to produce a single observation for each clump since the missing rates of mussels from 2 positions within a clump is not independent (Peterson \& Renaud 1989). Then I transformed the differences of proportions with angular transformation (Sokal \& Rohlf 1981), before applying Student's $t$-test. Results demonstrated that mussels living on the edge of the clumps experienced significantly higher $(p<0.001)$ disappearance rates than those in the center when data were pooled over locations, marshes, and years.

A 2-factor [location (1 to 5) and date (May 24-25 and $27-28,1988)]$ Model I MANOVA revealed that location (Wilks' Lambda, $F_{8 / 78}=44.66, p<0.0001$ ), data (Wilks' 
Lambda, $F_{2 / 39}=21.88, p<0.0001$ ) and their interaction (Wilks' Lambda, $F_{8 / 78}=7.82, p<0.0001$ ) all significantly affected mussel mortality at Sapelo Island (Cochran's test showed no significant difference in variance among the treatments at 0.05 level). Because of the significant interaction between location and date, and the high correlation between the number of mussels missing at 2 positions within the clumps (the first characteristic root is $>98 \%$ for each term), the 2 experimental dates were analyzed separately to compare disappearance rates of mussels for each position within the clumps among the 5 locations.

Between May 24 and 25, the tide did not rise enough to cover the marsh flat (Locations 3 to 5) and all the mussels there survived (Fig. 2). However, mussels at both lower elevations (Locations 1 and 2) suffered high mortality (Fig. 2). A Tukey multiple comparison test showed that the missing rates of mussels among the

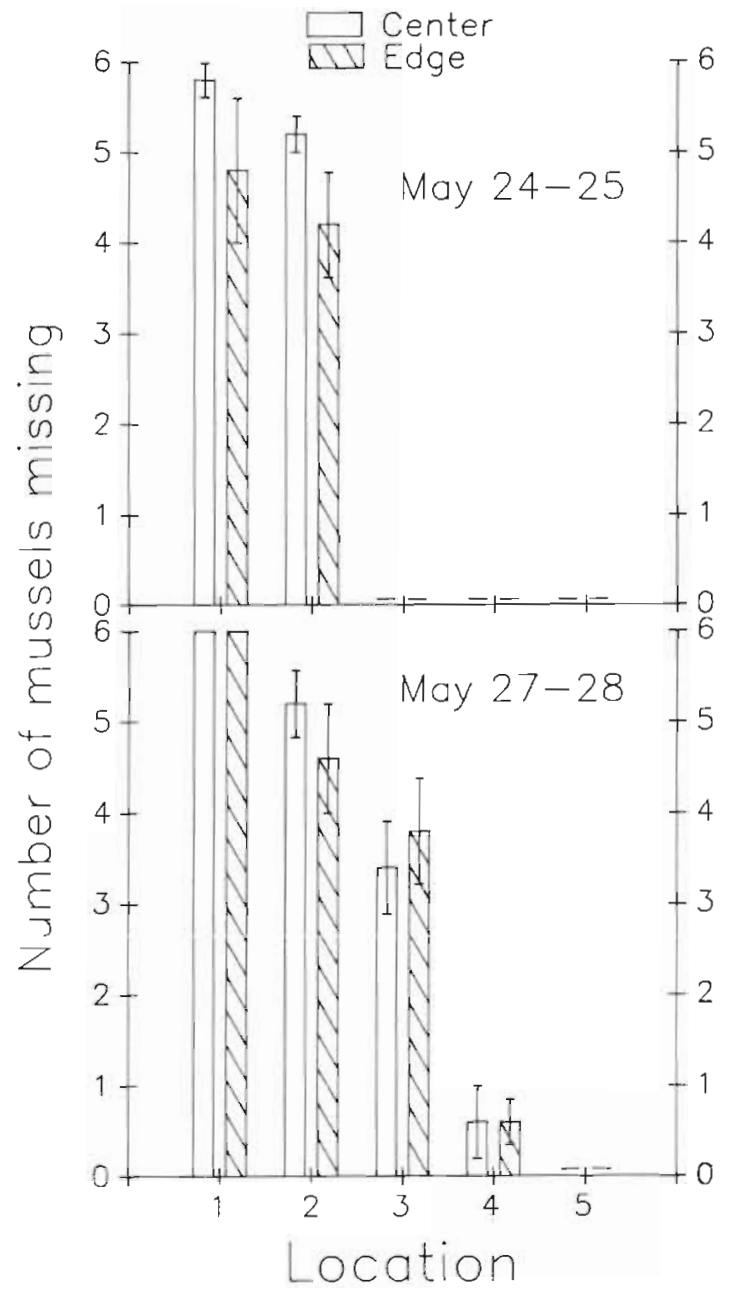

Fig. 2. Geukensia demissa. Mean number of mussels missing ( \pm SE) from 2 positions within clumps at 5 locations in the Sapelo Island marsh for 2 experimental periods. Sample size for each bar $=5$ locations were in the following order $(\alpha$ at 0.05$): 1=2>$ $3=4=5$ for either position.

Between May 27 and 28, the tide covered all 5 locations. Mussels from all locations except 5 suffered at least some mortality (Fig. 2). A Tukey multiple comparison test revealed that for mussels living in either position of the clumps, missing rates among the locations were in the following order $(\alpha$ at 0.05$): 1=2>3>4=5$.

There was no significant difference ( $t$-test, $p>0.5)$ in mortality between mussels at the edge and center of the clumps when the data were pooled over locations and dates as tested by a paired t-test on angulartransformed differences as described above.

All the mussels at Locations 3 to 5 survived between May 24 and 27, when the tidal water never covered the marsh flat.

\section{DISCUSSION}

The cause of mussel disappearance in this study was probably predation by blue crabs Callinectes sapidus. The experimental mussels were relatively large (60 to $70 \mathrm{~mm}$ shell height) and beyond the critical size that resident mud crabs Panopeus herbstii can consume (Seed 1980). Blue crabs have been shown to be voracious predators on molluscs (e.g. Laughlin 1982), capable of consuming large numbers of ribbed mussels over a wide size range (up to $80 \mathrm{~mm}$ shell height) in the laboratory during short periods of time (Seed 1980, Hughes \& Seed 1981). They also appear to be the primary predator on Geukensia demissa in a New England (USA) salt marsh (Bertness \& Grosholz 1985). Blue crabs are abundant in all my study areas during much of the year (Dudley \& Judy 1971, pers. obs.). In predator inclusion cages in an Alabama (USA) salt marsh, however, blue crabs rarely chose G. demissa but exhibited preference for periwinkles Littorina irrorata and killifish Fundulus similis (West \& Williams 1986). Under natural conditions, however, L. irrorata climbs up Spartina culms to avoid predation by blue crabs (Hamilton 1976, Warren 1985). Blue crabs can capture the highly moblle $F$. similis only be waiting motionless for a fish to swim by (West \& Williams 1986). Cage confinement may severely affect the predator avoidance capabilities of these 2 mobile prey species and substantially inflate the blue crabs' preferences on them over ribbed mussel

Okamura (1986) demonstrated that in blue mussel Mytilus edulis clumps, individuals living on the edge suffer higher mortality from crab predation than those in the center of the clump. This was also true in the ribbed mussel clumps at the 2 Morehead City marshes. At the Sapelo Island marsh, however, mussels from both positions displayed similar mortalities. 
Predation by terrestrial predators (e.g. wading birds, raccoons) seemed to have little, if any, impact on the ribbed mussels, as suggested by the complete survivorship during a $72 \mathrm{~h}$ period when tidal water did not cover the marsh flat of Sapelo Island and by a study carried out in a New England salt marsh (Bertness \& Grosholz 1985). Wading birds have been shown to be important predators on intertidal sand/mud flats (e.g. Hulscher 1982, Quammen 1984, Ambrose 1986). The lack of bird predation on the mussels in salt marshes may be due to dense Spartina grasses impeding the movement of birds.

It is unlikely that natural mussels would suffer such a high mortality rate as the experimental mussels did in the present study. When I put the mussels out in the field, I inevitably disturbed the general vicinity around the experimental clumps. This artificial disturbance may attract predators and as a consequence inflate mortality rates (Gardner 1984). However, there is little reason to suspect that this artifact is not a systematic error among all treatments. Predation rate on the experimental mussels in these southern marshes was much higher than on those in a New England marsh (Bertness \& Grosholz 1985). The very high density of experimental mussels which reflected the local mussel abundance in the New England marsh (covering from 50 to $96 \%$ of available marsh surfaces; Bertness \& Grosholz 1985) may explain the low mortality there. Interestingly, no mussels larger than $36.2 \mathrm{~mm}$ were crushed by predators in the New England marsh experiment (Bertness \& Grosholz 1985), whereas the mussels in my study were almost twice as large and suffered mortality. In the laboratory, blue crabs have been shown to prefer small ribbed mussels (Seed 1980, Hughes \& Seed 1981) which were abundant in the New England marsh (Bertness \& Grosholz 1985).

The present study shows that the intensity of predation on mussels generally decreased with increasing tidal elevation in salt marshes from 2 geographical areas. The same pattern was found in a New England salt marsh (Bertness \& Grosholz 1985). The likely explanation for the pattern is that time of submergence and therefore time available for blue crabs and other aquatic predators to forage decreases with increasing tidal elevation. In the rocky intertidal, the diversity of predators and their impacts on barnacles or mussels also decreases from low to high shore levels (Connell 1961a, b, 1970, 1975, Dayton 1971, Paine 1974).

At similar tidal elevations, mussels living further away from the water-marsh edge suffer less mortality. This may be due to aquatic predators having to travel through dense marsh grasses to reach the marsh interior. The effect of dense vegetation as partial refuge from predators in the seagrass beds has been well documented (e.g. Nelson 1979, Heck \& Thoman 1981,
Peterson 1982, Summerson \& Peterson 1984). At similar elevations in the rocky intertidal zone, predatory fishes, crabs (Menge \& Lubchenco 1981), and shorebirds (Frank 1982, Marsh 1986) prey heavily on open, smooth surfaces and tops of boulders but had little impact on algae and invertebrates living in crevices, holes, and sides of boulders where they were less accessible. Ogden et al. (1973) demonstrated that grazing by the sea urchin Diadema antillarum during nocturnal migrations off the coral reefs was responsible for the heavily grazed grass zone ('halo') between the reefs and seagrass communities. The urchins may limit their foraging distance away from the reef which provide some protection from their predators. Similar patterns may also occur for predators that take cover in seagrass beds during the daytime and forage on nearby sandy bottoms at night (Summerson \& Peterson 1984). Many important predators in rocky intertidal habitats are sluggish aquatic animals like starfish and snails (e.g. Connell 1961a, b, 1970, 1975, Paine 1974, Menge 1978, 1983) whose foraging time is limited to periods of tidal inundation. Therefore the horizontal distance away from open water could have a large impact on the predatory pattern of these animals. A given distance at a given elevation may not have as much of an effect on highly mobile aquatic animals (e.g. crabs and fishes), which are the most important predators in the soft sediment intertidal zones. On the other hand, these soft-bottom intertidal areas (mud/sand flat, salt marsh, and mangrove) are in general more extensive than rocky shores. In addition, in habitats like salt marshes and mangroves, physical structure (marsh grasses and mangrove trees) may interfere with the movement and/ or foraging activities of the animals.

Acknowledgements. I thank C. H. Peterson for valuable advice throughout the study. M. Britt, T. Little, J. Purifoy, G. Safrit, and F. Wang provided laboratory and/or field assistance. D. Colby, S. Ortega, and J. P. Sutherland helped in data analyses. I thank J. Cahalan, D. Colby, M. E. Hay, C. H. Peterson, C. Prescott, A. E. Stiven, J. P. Sutherland, F. Wilson and 3 anonymous reviewers for their comments on earlier drafts of the manuscript. The University of Georgia Marine Institute and R. T. Kneib kindly provided accomodation and facilities during my stay at Sapelo Island. Financial support was provided by the Curriculum in Marine Sciences, and Institute of Marine Sciences of University of North Carolina at Chapel Hill and an NSF grant OCE 8620210 to C. H. Peterson.

\section{LITERATURE CITED}

Ambrose, W. G. Jr. (1986). Estimate of removal rate of Nereis virens (Polychaeta: Nereidae) from an intertidal mud flat by gulls (Larus spp.). Mar. Biol. 90: 243-247

Bertness, M. D. (1984). Ribbed mussels and Spartina alterniflora production in a New England salt marsh. Ecology 65: 1794-1807

Bertness, M. D., Grosholz, E. (1985). Population dynamics of the ribbed mussel, Geukensia demissa: the costs and 
benefits of an aggregated distribution. Oecologia (Berl.) 67: 192-204

Connell, J. H. (1961a). Effects of competition, predation by Thais lapillus, and other factors on natural populations of the barnacle Balanus balanoides. Ecol. Monogr 31: $61-104$

Connell, J. H. (1961b). The influence of interspecific competition and other factors on the distribution of the barnacle Chthamalus stellatus. Ecology 42: 710-723

Connell, J. H. (1970). A predator-prey system in the marine intertidal region. I. Balanus glandula and several species of Thais. Ecol. Monogr. 40: 49-78

Connell, J. H. (1975). Some mechanisms producing structure in natural communities: a model and evidence from field experiments. In: Cody, M. L., Diamond, J. (ed.) Ecology and evolution of communities. Belknap, Cambridge, Mass., p. 460-490

Dayton, P. K. (1971). Competition, disturbance and community organization: the provision and subsequent utilization of space in a rocky intertidal community. Ecol. Monogr. 41 $351-389$

Dudley, D. L., Judy, M. H. (1971). Occurrence of larval, juvenile, and mature crabs in the vicinity of Beaufort Inlet, North Carolina. NOAA Tech. Rep., NMFS SSRE-637, Washington, D.C.

Frank, P. W. (1982). Effects of winter feeding on limpets by black oystercatchers, Haematopus bachmani. Ecology 63: 1352-1362

Gardner, S. A. (1984). The influence of clumping on population dynamics of the ribbed mussel, Geukensia demissa. M.S. thesis, University of North Carolina at Chapel Hill

Hamilton, P. V. (1976). Predation of Littorina irrorata by Callinectes sapidus. Bull. mar. Sci. 26: 403-409

Heck, K. L. Jr., Thoman, T A. (1981). Experiments on predator-prey interactions in vegetated aquatic habitats. J. exp mar. Biol. Ecol. 53: 125-134

Hughes, R. N., Seed, R. (1981). Size selection of mussels by the blue crab Callinectes sapidus: energy maximizer or time minimizer? Mar. Ecol. Prog. Ser. 6: 83-89

Hulscher, J. B. (1982). The oystercatcher as a predator of Macoma. Ardea 70: 89-152

Irons, D. B., Anthony, R. G., Estes, J. A. (1986). Foraging strategies of Glaucous-winged gulls in a rocky intertidal community. Ecology 67: 1460-1474

Kneib, R. T (1984). Patterns of invertebrate distribution and abundance in the intertidal salt marsh: causes and questions. Estuaries 7: 392-412

Kuenzler, E. J. (1961). Structure and energy flow of a mussel population in a Georgia salt marsh. Limnol. Oceanogr. 6 : 191-204

Laughlin, R. A. (1982). Feeding habits of the blue crab, CalLinectes sapidus Rathbun, in the Apalachicola Estuary, Florida. Bull. mar Sci. 32: 807-822

Lin, J. (1989). Influence of location in the salt marsh and clump size on the growth of ribbed mussels. J. exp. mar Biol Ecol. (in press)

Marsh, C. P. (1986). Rocky intertidal community organisation the impact of avian predators on mussel recruitment. Ecology $67 \cdot 771-786$

Menge, B. A. (1978). Predation intensity in a rocky intertidal

This article was presented by Professor $R$. B. Forward, Beaufort, N. Carolina, USA community - Relation between predator foraging activity and environmental harshness. Ocecologia (Berl.) 34: 1-16

Menge, B. A. (1983). Components of predation intensity in the low zone of the New England rocky intertidal region Oecologia (Berl.) 58: 141-155

Menge, B. A., Lubchenco, J. (1981). Community organization in temperate and tropical rocky intertidal habitats: prey refuges in relation to consumer pressure gradients. Ecol. Monogr. 51: 429-450

Nelson, W. G. (1979). Experimental studies of selective predation on amphipods: consequences for amphipod distribution and abundance. J. exp. mar. Biol. Ecol. 38: 225-245

Ogden, J. C., Brown, R. A., Salesky, N. (1973). Grazing by the echinoid Diadema antillarum Philippi: formation of halos around West Indian patch reefs. Science 182: 715-717

Okamura, B. (1986). Group living and the effects of spatial position in aggregations of Mytilus edulis. Oecologia (Berl.) 69: 341-347

Paine, R. T (1974). Intertidal community structure - experimental studies on the relationship between a dominant competitor and its principle predator. Oecologia (Berl.) 15 $93-120$

Peterson, C. H. (1982). The importance of predation and intraand interspecific competition in the population biology of two infaunal suspension-feeding bivalves, Protothaca staminea and Chione undatella. Ecol. Monogr. 52 . $437-475$

Peterson, C. H., Renaud, P. E. (1989). Analysis of feeding preference experiments. Oecologia (Burl) (in press)

Quammen, M. L. (1984). Predation by shorebirds, fish, and crabs on invertebrates in intertidal mud flats: an experimental test. Ecology 65: 529-539

Seed, R. (1980). Predator-prey relationships between the mud crab Panopeus herbstii, the blue crab. Callinectes sapidus, and the Atlantic ribbed mussel Geukensia (= Modiolus) demissa. Estuar coast. mar. Sci. 11. 445-458

Sokal, R. R., Rohlf, F. J. (1981). Biometry, 2nd edn. W H Freeman \& Co., San Francisco

Stiven, A. E., Kuenzler, E. J. (1979). The response of two salt marsh molluscs, Littorina irsorata and Geukensia demissa, to field manipulations of density and Spartina litter. Ecol. Monogr. 49: 151-171

Summerson, H. C., Peterson, C. H. (1984). Role of predation in organizing benthic communities of a temperate-zone seagrass bed. Mar. Ecol. Prog. Ser. 15: 63-77

Underwood, A. J., Denley, E. J. (1984). Paradigms, explanations, and generalizations in models for the structure of intertidal communities on rocky shores. In: Strong, D. R. Jr., Simberloff, D., Abele, L. G., Thistle, A. B. (ed.) Ecological communities - conceptual issues and the evidence. Princeton University Press, p. 151-180

U.S. Department of Commerce, National Oceanic and Atmospheric Administration, National Ocean Service (1988) Tide tables 1989: East coast of North and South America

Warren, J. H. (1985). Climbing as an avoidance behaviour in the salt marsh periwnkle, Littorina irrorata (Say). J. exp mar Biol. Ecol. 89: 11-28

West, D. L., Williams, A. H. (1986). Predation by Callinectes sapidus (Rathbun) within Spartina alterniflora (Loisel) marshes. J. exp. mar. Biol. Ecol. 100: 75-95

Manuscript first received: December 19, 1988

Revised version accepted: May 25, 1989 